DOI: $10.26693 / j m b s 06.06 .267$

UDC 573.4:614.777

Mintser O. P. ${ }^{1}$, Pesotskaya L. A. ${ }^{2}$, Gorovaya A. I. ${ }^{3}$, Glukhova N. V. ${ }^{3}$, Shchukina O. S. ${ }^{4}$

\title{
INFLUENCE OF COHERENT PROPERTIES OF WATER ON BIOLOGICAL GROWTH OF PLANTS
}

\author{
${ }^{1}$ National University of Health Protection of Ukraine named after L. Shupyk, \\ Kyiv, Ukraine \\ 2 Dnipro State Medical University, Ukraine \\ ${ }^{3}$ NTU “Dniprovska Polytechnic", Dnipro, Ukraine \\ ${ }^{4}$ Dnipro State Medical University, Ukraine
}

The purpose of the research was to study the effect of Allium cepa $L$ on the growth processes of the coherent properties of various water sources and samples of distilled and natural water with the electrophysical properties of the original samples transferred to them.

Materials and methods. The Kirlian gas-discharge glow of water droplets was recorded on an $X$-ray film. We used histograms of the luminescence corona brightness, calculated the values of the Euclidean distance for the medians of the heights of the histogram columns and for the differences in the medians in adjacent intervals. The values during of the research were compared with similar parameters of pre-formed samples of images of typical waters (distilled, tap water, from natural sources outside and from the territories of monasteries), as well as water samples with an established type and degree of coherence. The objects of the growth test were onion plants - Allium cepa L. The height of the seedlings, the length of the roots were estimated, and their dry weight was determined.

Results and discussion. The identity of the signs of coherence in most samples of electrophysical (energy-informational) copies of water from original sources, the correspondence between the results of the growth test and the properties of water coherence were revealed. There was an increase in the biomass of the test culture when grown on samples with dextrorotatory coherence of water as its degree increased. With levorotatory polarization of water coherence, the biomass decreases with an increase in its degree. The study showed the possibility of transferring the electrophysical properties of various samples of natural water both to distilled water and to other water samples from natural sources. We experimentally demonstrated the possibility of transferring the quantum properties of liquid-phase objects for the preparation and use of biologically active substances in agriculture, biology and medicine without their side effects.

Conclusion. Kirlian photography of water can be used as an additional way of express-indication of the physical state of the water basins of the biosphere, including the quality of drinking water by their coherent properties. It is perspective to study the effects of water sources with certain coherent properties on the growth processes of certain plant species and their parts.

Keywords: water coherence, electrophysical water copies, test-culture, onion, Kirlian photography.

Research relation to the plans, programs and department themes. This work is a fragment of the research work "Dynamical modes of geotechnical systems" state registration number 0117 U003056

Introduction. Recent discoveries in the field of physics of water related to its structure [1] have shown that the biological processes of living things are significantly affected by the coherence of water [2, 3]. Modern ideas about the structure and properties of water are based on the inhomogeneity of its components, phase transitions, and quantum effects.

For at least 30 years in the world scientific literature, evidence has been provided for the heterogeneity of the structure of distilled, bidistilled and deionized water and aqueous solutions at the microlevel, obtained by different physical methods. It is shown that the surface of these microstructures is negatively charged with respect to the environment.

Literature data and our own observations show that water and aqueous solutions are microdispersed systems in which water is present in two phases - free (continuous) and bound - liquid crystalline water of hydration shells of hydrophilic microparticles $[4,5,6]$.

The active principle governing the information perceived by the cell or cellular organelles is the complex geometric shape of water associates. It is the link that determines the structure of the physical fields inherent in the associate. The same fields, in turn, trigger or inhibit intracellular molecular processes [3].

This opens up the possibility of transferring the quantum properties of liquid-phase objects in the preparation of therapeutic drugs without side effects [3,7-10] and biologically active substances for use in agriculture, biology and medicine.

The study of such material processes will be reduced to registering changes in their electrophysical 
properties. Such a possibility is possessed by methods based on the Kirlian Effect, which is based on the formation of a gas-discharge glow corona around any object of animate and inanimate nature in a high-frequency field [11].

Previously, we identified Kirlian-photographic parameters of the glow corona of experimentally prepared coherent water by the method [12] with using samples of distilled and natural drinking water with statistic analysis of results. According to the criteria of histograms of the brightness of the glow of Kirlianograms, we revealed statistically significant differences between the groups of water samples that gave intensive and weak growth test culture of Allium cepa L. (bow) according to histograms of the corona brightness of the Kirlianograms [13]. The Kirlian image of the samples records the coherent properties of water.

On the other hand, the authors [14] observed the formation of a "new solid phase of water" - micron-sized particles - after repeated shaking of ultrapure water. The formation of this phase, according to the authors, proceeded through the formation of "coherent domains". This additional phase participates in the reactions of water to external influences. All of them lead to the same consequences - increasing $\mathrm{pH}$, decreasing in ORP, increasing in electrical conductivity, and decreasing in viscosity. All of these increase the bioavailability of water for plants and animals. There is a correspondence between the coherent properties of water and its bioavailability. In our case, this should manifest itself on the correspondence of the type and degrees of coherence of water samples to the results of onion growth.

A cascade of changes in the physicochemical properties of water, characteristic of its activated form, is associated with the degassing of liquids. Processes are considered at different levels of the hierarchy - nanometer and micrometer. The area of the negatively charged surface increases, which leads to an increase in the "seats" for hydronium ions, which results in an increase in $\mathrm{pH}$ [15]. The basis of Kirlian photography is a gas discharge between the object and the film, with UV radiation captured by the X-ray film. It is obvious that the degassing state of the water sample is displayed in the image of the glow corona around the droplet.

It seemed to us advisable to compare these results with each other for the possible application of the results obtained in solving theoretical and practical problems of biology and ecology.

The purpose of the research was to study the influence of the coherent properties of various water sources on the growth processes of Allium cepa L. using the registration of their Kirlian gas-discharge glow.

Materials and methods. The object of the study was onion plants - Allium cepa L., grown in various water sources. The biological experiment consisted of placing bulbs of the same size $(1-1.5 \mathrm{~cm})$ on a moist substrate moistened with different germination waters for 3 weeks. The height of the seedlings and the length of the roots were measured, and their dry weight was determined.

Natural waters from the springs of Bulgaria were used as original waters, including those from the territories of monasteries (the rocky monastery of Madara, the Drensky monastery, the monastery of Saints Peter and Paul), as well as tap water from cities Varna and Gabrovo, and from the Holy Natural Spring of Ukraine (Primorsk). Samples of distilled (DW) and natural well water (NWW) were used as control samples. Samples of quantum copies from original waters (energy-information copies-IC) were experimentally prepared on them using a device for energy-information transfer and a method for their identification $[16,17]$.

To obtain a Kirlian image of water samples, we used an X-ray film and an experimental device with an attachment for liquid-phase objects.

Earlier, we created a database of Kirlian-images (Ki) on X-ray film for several types of water. The following were used as typical waters (TW): distilled water (1), tap water (TapW, 2), natural water outside the monasteries (3) and water from the territories of monasteries (4). When constructing an automated classification system by water types, the construction of histograms was used as the main method for comparing the geometric and photometric (brightness) characteristics of images.

Kirlianograms of water drops, in the amount of 50 for each experimental sample, were scanned and according to brightness corona lightening $(\mathrm{BCL})$ the values of the Euclidean distance for the medians (EDM) of the heights of the histogram columns, as well as the Euclidean distance of the median differences (EDMD) in adjacent intervals with the values of the typical waters parameters. The smallest values of the Euclidean distance indicate the maximum closeness of the test sample to one of the typical classes of water.

Fig. 1 shows images and corresponding histograms of pixel brightness for selected typical water classes.

Results and discussion. The results of the growth for the test water samples are presented in Table 1.

The results obtained suggest that the processes of biological growth on IC samples from the original depend on its physical properties. In particular, IC samples prepared on distillate and water from NWW from the water of the Holy Spring (Primorsk) gave an intensive growth of the test culture in both cases. Whereas, in the original water samples from Primorsk and NWW, the growth was weak or absent due to the unfavorable chemical composition. In the 
(a)
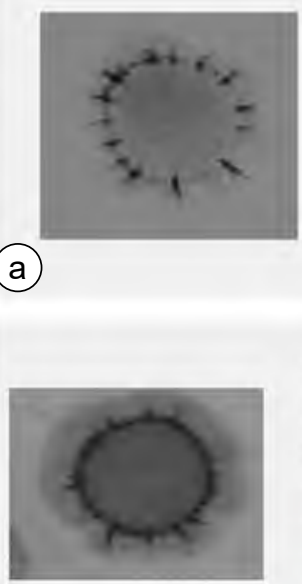

(c)
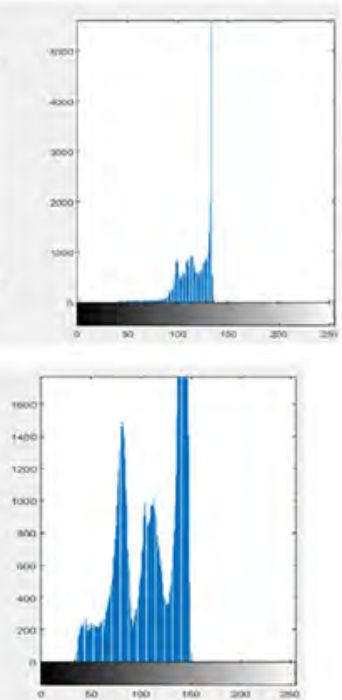

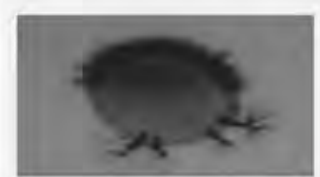

(b)

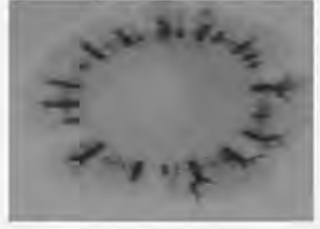

(d)
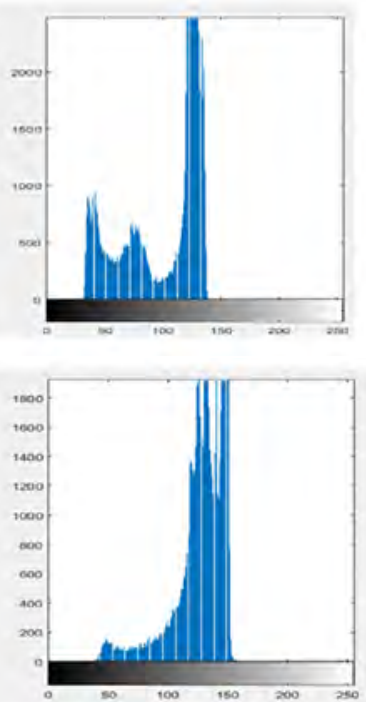

Fig. 1 - Analysis of images of water:

a - distilled, b - tap water, c - natural, d - from a monastery source (on the left - an image of gas-discharge radiation recorded on an X-ray film; on the right - a histogram of pixel brightness)

Table 1 - Results of the growth test with the culture of Allium cepa L. for different water sources

\begin{tabular}{|c|c|c|c|c|c|c|}
\hline \multicolumn{7}{|c|}{ Intense growth } \\
\hline \multirow[b]{2}{*}{ Water source / pH } & \multicolumn{3}{|c|}{ Green sprouts } & \multicolumn{3}{|c|}{ Roots } \\
\hline & $\begin{array}{c}\text { Quantity, } \\
\text { Nos. }\end{array}$ & $\begin{array}{c}\text { Average } \\
\text { height } \\
(\mathrm{cm})\end{array}$ & $\begin{array}{c}\text { Dry } \\
\text { weight } \\
\text { (mg) }\end{array}$ & $\begin{array}{l}\text { Quantity, } \\
\text { Nos. }\end{array}$ & $\begin{array}{c}\text { Average } \\
\text { length } \\
(\mathrm{cm})\end{array}$ & $\begin{array}{c}\text { Dry } \\
\text { mass }(\mathrm{mg}) / \\
\text { total }\end{array}$ \\
\hline From Primorsk copy on distil/ 3.9 & 5 & 6.8 & 200 & 20 & 5.3 & $50 / 250$ \\
\hline From Primorsk copy on NWW / 5.0 & 6 & 13.3 & 200 & 2.6 & 6.6 & $100 / 300$ \\
\hline Varna copy on NWW / 5.4 & 5 & 5 & 250 & 2.6 & 2 & $50 / 300$ \\
\hline Mineral original water / 4.4 & 4 & 5 & 100 & 17 & 9.3 & $100 / 200$ \\
\hline Mineral water copy on distil/ 4.6 & 2 & 2 & 50 & 18 & 6.4 & $50 / 100$ \\
\hline Mineral water copy on NWW/ 4.9 & 6 & 11.1 & 200 & 16 & 4.6 & $50 / 250$ \\
\hline From the Drensky mon-ry original / 4.7 & 4 & 7.4 & 200 & 12 & 6.7 & $50 / 250$ \\
\hline From the Drensky mon-ry copy on distil / 5.2 & 4 & 7.8 & 100 & 17 & 9.3 & $100 / 200$ \\
\hline The Drensky mon-ry water copy on NWW/ 5.3 & 6 & 9.7 & 200 & 11 & 7.9 & $50 / 250$ \\
\hline Madara original/ 4.7 & 5 & 9.6 & 300 & 22 & 6.9 & $50 / 350$ \\
\hline Madara copy on NWW / 5.2 & 5 & 4 & 50 & 21 & 3.4 & $100 / 150$ \\
\hline From M. Peter and Paul original / 4.8 & 2 & 1.2 & 50 & 12 & 6 & $100 / 150$ \\
\hline From M. Peter and Paul copy on distil/ 4.6 & 3 & 2.2 & 100 & 14 & 4.4 & $100 / 200$ \\
\hline From M. Peter and Paul copy on NWW / 5.4 & 4 & 7.6 & 100 & 35 & 9.1 & $100 / 200$ \\
\hline Gabrovo copy on NWW / 5.1 & 1 & 2.5 & 50 & 9 & 2.4 & $50 / 100$ \\
\hline \multicolumn{7}{|c|}{ Weak growth } \\
\hline & \multicolumn{3}{|c|}{ Green sprouts } & \multicolumn{3}{|c|}{ Roots } \\
\hline Water source / pH & $\begin{array}{c}\text { Quantity, } \\
\text { Nos. }\end{array}$ & $\begin{array}{c}\text { Average } \\
\text { height } \\
(\mathrm{cm})\end{array}$ & $\begin{array}{c}\text { Dry } \\
\text { weight } \\
\text { (mg) }\end{array}$ & $\begin{array}{c}\text { Quantity. } \\
\text { Nos. }\end{array}$ & $\begin{array}{c}\text { Average } \\
\text { length } \\
(\mathrm{cm})\end{array}$ & $\begin{array}{c}\text { Dry } \\
\text { mass }(\mathrm{mg}) / \\
\text { total CM }\end{array}$ \\
\hline Distilled water control / 7.0 & 0 & - & - & 0 & - & - \\
\hline Well water control / 5.8 & 4 & 1.8 & 40 & 13 & 2.3 & $50 / 90$ \\
\hline Primorsk original / 6.8 & 1 & 1.2 & 50 & - & - & $0 / 50$ \\
\hline Varna original / 4.5 & 0 & - & - & 12 & 0.8 & $25 / 25$ \\
\hline Varna copy on distil / 4.5 & 0 & - & - & 0 & - & - \\
\hline Madara copy distilled / 4.2 & 1 & 0.2 & 12 & 42 & 3.6 & $50 / 70$ \\
\hline Gabrovo original / 4.1 & 0 & - & - & 14 & 2.5 & $50 / 50$ \\
\hline Gabrovo copy on distil / 4.3 & 0 & - & - & 8 & 1.2 & $25 / 25$ \\
\hline
\end{tabular}


water from the city of Primorsk, the content of nitrates was higher, in the water from the NWW there were iron compounds. The explanation of the appearance of the biological activity of IC can be explained from the concept of the quantum nature of water.

It is known that the main reservoir of free energy in biological systems are electronically excited states of complex molecular complexes. These states are continuously maintained due to the circulation of electrons in the biosphere. The flow of a pulsed electric current in non-conducting biological tissues can be provided due to the intermolecular transfer of excited electrons by the mechanism of the tunnel effect with activated electron hopping in the contact region between macromolecules [18]. The described mechanisms of energy transfer are inherent in water to varying degrees, depending on the degree of its ordering [19]. The role of water, its coherent domains in the formation of meanings, starting from information obtained from perception, is emphasized [20]. Obviously, these mechanisms take place in the experimentally obtained samples of structural information copies from the original samples of natural water, containing a certain amount of a biological substance.
According to Roberto Germano [21], coordinated domains of water with low energy and high entropy under certain conditions can be restructured, becoming high-energy with low entropy, capable of external work. Apparently, the restructuring in the original control water samples, on which the structural information transfer from the original waters was made, was the source of the new quantum coherence required for biological processes in the growth test. Coherent phenomena has a main role in almost all elementary processes of energy transfer in cells. The fact of the positive influence of coherent dynamics on the efficiency of energy transfer can be considered established [22]. The theory of quantum coherence experimental results were obtained at the University of California (USA) by the method of nuclear magnetic resonance (NMR) [23].

The results of the analysis of experimental water samples with experimental samples of three degrees $(1,2,3)$ of coherent water of the dextrorotatory type $(+)$ and levorotatory type (-), prepared with distilled water (KDW) and drinking water from a well (KWW) according to the parameters of their histograms brightness are presented in tables 2, 3.

Table 2 - Coherence of test water samples in the group of onion test culture with intense growth

\begin{tabular}{|c|c|c|c|c|c|c|c|c|c|c|c|c|c|c|c|}
\hline Samples & $\mathbf{1}$ & $\mathbf{2}$ & $\mathbf{3}$ & $\mathbf{4}$ & $\mathbf{5}$ & $\mathbf{6}$ & $\mathbf{7}$ & $\mathbf{8}$ & $\mathbf{9}$ & $\mathbf{1 0}$ & $\mathbf{1 1}$ & $\mathbf{1 2}$ & $\mathbf{1 3}$ & $\mathbf{1 4}$ & $\mathbf{1 5}$ \\
\hline $\mathrm{KG}$ & +1, & +1, & +1, & +1, & +1, & +2, & +2 & +2, & +2 & $+1 !$ & -1 & $+2 !$ & +2 & -1 & -1 \\
& $-1 !$ & +3 & -1.3 & -1.3 & -1.3 & +1, & -2 & +1, & -2 & $+2 !$ & +2 & $-2 !$ & +1 & +3 & +3 \\
& & -1.2 & & & & +3 & +1 & +3 & +1 & -2 & -2 & +1 & -2 & +1 & +1 \\
& & & & & & & +3 & & & +3 & +1 & +3 & & +2 & +2 \\
& & & & & & & & & & & & & & -3 & -3 \\
\hline
\end{tabular}

Table 3 - Coherence of test water samples in the group of onion test culture with weak growth

\begin{tabular}{|c|c|c|c|c|c|c|c|c|}
\hline $\begin{array}{c}\text { Water } \\
\text { samples }\end{array}$ & $\begin{array}{c}\text { Distil. } \\
\text { water }\end{array}$ & $\begin{array}{c}\text { Water } \\
\text { on NWW }\end{array}$ & $\begin{array}{c}\text { Primorsk } \\
\text { original }\end{array}$ & $\begin{array}{c}\text { Varna } \\
\text { origin. }\end{array}$ & $\begin{array}{c}\text { Varna on } \\
\text { dist. }\end{array}$ & $\begin{array}{c}\text { Madera } \\
\text { on dist. }\end{array}$ & $\begin{array}{c}\text { Gabrovo } \\
\text { original. }\end{array}$ & $\begin{array}{c}\text { Gabrovo } \\
\text { on dist. }\end{array}$ \\
\hline KG & +1, & +1, & +1, & $-1 !,+1$, & $+1,-1$ & $+1,+2$, & $+1,-1$ & $+1,-1$ \\
& $-13 !$ & $-1 !,-3 !$ & $-1 !,-3 !$ & $-3 !$ & & $-2,-1$ & & \\
\hline
\end{tabular}

Particular attention is paid to the identity of the signs of coherence in a number of IC samples from original sources prepared both with distilled water and with drinking water from a well.

Studies have revealed the regularities of the properties of the coherence of water, in accordance with the results of the growth test. In particular, attention is drawn to the diversity of types and degrees of coherence with a predominance of a certain type of it in the group of experimental water samples with intensive onion growth.

According to literature data, natural water has a mixed type of coherence, which determines the stability of its properties, which was more observed in the group of water samples with plants with intense growth, consists of two structures with different spin orientations of molecules, or in other words, L- and
R-polarized water. The influence of spin orientation on the properties of natural drinking water was studied. It was shown that natural water is a quantum system and, accordingly, exhibits special, new physical properties; particularly, such natural water is an inseparable physical medium, which manifests itself as a dynamically equilibrium environment that maintains its equilibrium over a long period of time. Water is defined as a two-structural medium, which has a coherent and incoherent structure [24].

This explains that the best biological growth was observed in water with different types of coherence or with different degrees of it. The consequence of this is the formation of the physical properties of water, optimal for biological systems.

Such an approach to the internal structure of water from the point of view of the living-nonliving 
relationship should be considered as an equilibrium of energy balance, structural features and dissolved impurities. When water enters a living organism, then due to its dissymmetry, this ratio shifts towards the living organism. Anisotropic cluster fractality, as one of the important physical characteristics, determines the natural quality of water. The most suitable for the human body is water with the listed quantum properties, defined as inseparable [25, 26].

The types of coherence of opposite polarization were revealed in some samples from the group with a weak growth test, but with the same degree. The literature contains information about certain differences in their properties. In particular, it was found that duality is also a consequence of the fact that natural water is energetically influenced by external factors of different origins, as a result of which the left and right water systems obtained using chips are not identical, and are not mirror images of each other [24]. Apparently, water samples of the group with low onion growth provide a certain biological growth, however, they do not have a degree of inseparability sufficient for optimal growth conditions.

In the group of experimental water samples with weak onion growth, there were other features: some of the samples lacked the predominant type of coherence; in other cases, levorotatory polarity of the $3^{\text {rd }}$ degree of coherence prevailed.

It is known that the levorotatory water type has a pronounced bactericidal effect. Particularly, it increases the production of interferon, the effectiveness of inhibition of viruses (vesicular stomatitis, herpes infection, HIV), as a result of which opportunistic diseases disappear; does not cause aberrations (breakdowns) of chromosomes and is not toxic [2, 3].

Obviously, this was associated with the weak growth of onions in the corresponding group of experimental water samples with a high degree of levorotatory polarity, which adversely affects biological life in general.

Comparative analysis of the biomass of the test culture of Allium cepa L. (onion) with different species and degree of coherence of the water source is presented in Table 4.

Attention is drawn to the increase in the biomass of the test culture of Allium cepa L. (onion) when grown on samples with dextrorotatory coherence of water as its degree increases. At the $2^{\text {nd }}$ degree of coherence, the growth of seedlings is weaker than at the $1^{\text {st }}$ degree of coherence, although the total dry weight became somewhat higher.

At levorotatory polarization of water coherence with increasing in its degree the biomass is reduced, especially at the $3^{\text {rd }}$ degree of coherence. At the second degree of coherence due to lower root mass there is intensification of growth of seedlings, as opposed to the results of growth of seedlings on water with (+2) degree of coherence.

Various effects of onion growth, with a predominance of sprouts or roots with the corresponding dry matter mass, have a promising use of water with a definite set of coherent properties to optimize the biological activity of the necessary parts of plants. Further research is required to study the processes of biological growth depending on the quantum state of the water sources used.

\section{Conclusion}

1. The possibility of using the Kirlian photography method to determine the effect of water with different coherent properties on the biological growth of plants was established using the example of the test culture of Allium cepa L. (onion).

2. The method of Kirlian photography of water can be used as an additional method for express-indication of the state of water basins of the biosphere, including the quality of drinking water by their coherent properties.

3. The conducted biological experiment demonstrated the possibility of transferring the electrophysical properties of various samples of natural water both to distilled water and to other water samples from natural sources.

Table 4 - Comparative analysis of the biomass of the test culture of Allium cepa L. (onion) for different types and degree of coherence of water samples

\begin{tabular}{|c|c|c|c|c|c|c|c|c|c|c|c|c|c|c|c|c|c|c|}
\hline $\begin{array}{c}\text { Bio } \\
\text { weight/ } \\
\text { cohe- } \\
\text { rence }\end{array}$ & $+\mathbf{+ 1}$ & $\mathbf{+ 1}$ & $\mathbf{+ 1}$ & $\mathbf{+ 2}$ & $\mathbf{+ 2}$ & $\mathbf{+ 2}$ & $\mathbf{+ 3}$ & $\mathbf{+ 3}$ & $\mathbf{+ 3}$ & $\mathbf{- 1}$ & $\mathbf{- 1}$ & $\mathbf{- 1}$ & $\mathbf{- 2}$ & $\mathbf{- 2}$ & $\mathbf{- 2}$ & $\mathbf{- 3}$ & $\mathbf{- 3}$ & $\mathbf{- 3}$ \\
\hline $\mathrm{n}$ & 19 & 12 & 21 & 11 & 11 & 11 & 8 & 8 & 8 & 11 & 13 & 14 & 8 & 8 & 8 & 7 & 7 & 8 \\
\hline $\begin{array}{c}\mathrm{E} \\
(\mathrm{mg})\end{array}$ & 2260 & 1300 & 3560 & 1370 & 800 & 2170 & 1200 & 600 & 1800 & 1110 & 1800 & 1910 & 1120 & 600 & 1720 & 640 & 425 & 1065 \\
\hline $\begin{array}{c}\text { Av. } \\
(\mathrm{mg})\end{array}$ & 119 & 65 & 184 & 68 & 73 & 197 & 150 & 75 & 225 & 101 & 138 & 239 & 140 & 75 & 215 & 91 & 60 & 133 \\
\hline
\end{tabular}

Notes: $\mathrm{dw}$ - dry weight, $\mathrm{U}$ - upper green sprouts, $\mathrm{R}$ - roots; $\mathrm{CH}$ - coherence of a water sample. 
Perspectives of further research. It is perspective in the future to study the effect of water sources with a certain coherence on the growth processes of plants, including those weakened by various diseases, using various phytotests, and automating the results obtained. It is recommended to study the se- lection of water sources with certain coherent properties, according to the criteria of Kirlian photography, to improve the breeding properties of specific plants in accordance with known research methods in biology, ecology and agriculture.

\section{References}

1. Conference on the Physics, Chemistry, and Biology of Water. Sofia, Bulgaria, 2017 Oct 26-29. 2017. Available from: http://www.waterconf.org/participants-materials/2017/

2. Krasnobryzhev VG, Kurik MV. Properties of coherent water. Quantum Magic. 2010;7(2):2161-66.

3. Krasnobryzhev V. Global technological resource of macroscopic disloyalty. Coherent technology. Complementary coherent water. LAP Lambert Academic Publishing; 2012. 120 p.

4. Kurik MV, Pesotskaya LA, Glukhova NV, Evdokimenko NM. Kirlinography of energy-informational interactions of water. Lithographer; 2015.

5. Yakhno TA, Yakhno VG, Zanozina VF. Phase transitions of water as a source of slow oscillatory processes in liquid media. Topical issues of biological physics and chemistry. In: BFF-2017: materials of the XII international scientific and technical conference. 2017 Oct 2-6. 2017. p 23-27.

6. Yakhno TA, Yakhno VG. Microstructure and phase transitions of water according to optical microscopy data. Proceedings of the second all-Russian conference "Physics of aqueous solutions"; 2019 Oct 17-18. 2019. p 44-45.

7. Surinov BP, Khachumova KG, Germanov EP, Fedorenko AA. Informational pharmacology is the reproduction of information copies of medicinal substances in aqueous media. J Emerg Res Areas. 2017;15-16(5):85-91.

8. Surinov BP. Superweak radiation and modeling of the properties of biologically active substances. Overview. Radiation and risk. 2018;27(2):28-36. doi: 10.21870/0131-3878-2018-27-2-28-36

9. Khachumova KG, Surinov BP, Voeikov VL, Germanov EP, Fedorenko AA. Technologies that challenge modern thinking: the transmission of drug properties through communication lines. JFNN. 2014;2(5):108-117.

10. Etkin VA. On the technology of creating and transferring "information copies" of medicinal products. M: Samizdat; 2015.

11. Koltovoy NA. Kirlian method. Available from: https://koltovoi.nethouse.ru

12. Patent 207357 Poland. Sposób i urządzenie do modyfikacji paliwa [Method and equipment for fuel modification] I Krasnobryzhev VG. (PI). filing date 05.09.06 ; publ 05.03.07. Byul № 7. [Poland]

13. Mintser OP, Pesotskaya LA, Gorovaya Al, Glukhova NV, Krachunov H, Evdokimenko NM. Using Kirlian photography of water to assess its biological properties. Int J Sustain Dev. 2021;2:56-64.

14. Yakhno TA, Yakhno VG. Investigation of the role of the microdispersed phase of water during its transition to the state of activation. J Biol Phys Chem. 2020 Sep;5(1):43-51.

15. Shatalov VM. Degassing as a mechanism of biological action of weak electromagnetic fields. 2012. Available from: www.biophys.ru/archive/congress2012/proc-p37-d.pdf

16. Patent 4224 U1 RF. Ustroystvo dlya energoinformatsionnoy peredachi lekarstvennykh svoystv preparatov, prigotovlennykh $v$ sootvetstvii $s$ gomeopaticheskim printsipom [A device for energy-informational transfer of medicinal properties of drugs prepared according to the homeopathic principle] / Mikhailov VA, Parkhomenko YuA. (RF); zayavl 19.05.04; opubl 17.07.06. Byul № 7. [Russian]

17. Patent 148443 Ukraine, MPK G01N 33/487 (2006.01), G01N 21/00. Sposib identyfikatsiyi informatsiynykh kopiy bioaktyvnoyi ridyny [Method for identifying information copies of a bioactive family] / Mintser OP, Pisotska LA, Glukhova NV. (UA); zayavnik i vlasnik patentu Pisotska LA (UA). № u202007084; zayavl 4.11.2020, opubl. 11.08.2021 p. Byul № 32. [Ukrainian]

18. Korotkov KG, Williams B, Visneski LA. Entropiya i energiya v biologicheskikh sistemakh. Biofizicheskiye mekhanizmy aktivnosti «energeticheskikh» meridianov [Entropy and energy in biological systems. Biophysical mechanisms of activity of "energy" meridians]. [Russian]. Available from: http://baikaldivo.ru/applications/ ecology/article_07.htm

19. Voeikov VL, Buravleva EV, Vilenskaya ND, Fedorenko AA. Proceedings of the XVIII International Scientific Congress "Science. Information. Consciousness". 2014. p 24-30.

20. Vitiello $G$. The language of water: from information to meaning. Scale-free neurodynamics in the dissipative many-body model of brain resource. Water Conference. Bad Soden Germany; 2014. Available from: https:// waterconf.org/

21. Germano R. Electron extraction from bi-distilled water. Water Conference. Bad Soden Germany; 2014. Available from: https://waterconf.org/ 
22. Kassal I, Yuen-Zhou J, Rahimi-Keshari S. Does coherence enhance transport in photosynthesis? J Phys Chem Lett. 2013;4:61-66. PMid: 26281724. doi: 10.1021/jz301872b

23. Medders GR, Babin V, Paesani F. Development of a "first principles" water potential with flexible monomers. III: Liquid phase properties J Chem Theory Comput. 2014 Aug 12;10(8):2906-10. PMid: 26588266. doi: 10.1021/ ct5004115

24. Kurik MV, Martsenyuk LS. On the inseparability of the structure of natural water. J Quantum Magic. 2012;9(3):31303142.

25. Kurik MV, Martsenyuk LS. The physical foundations of life. Lambert Academic Publishing; 2012.165 p.

26. Del Giudice E. Coherent quantum-electrodynamic organization of biochemical processes. J Emerg Dir Sci. 2014;4 (2):92-99.

\section{УДК 573.4:614.777 \\ ВПЛИВ КОГЕРЕНТНИХ ВЛАСТИВОСТЕЙ ВОДИ \\ НА БІОЛОГІЧНЕ ЗРОСТАННЯ РОСЛИН \\ Мінцер О. П., Пісоцька Л. А., Горова А. І., \\ Глухова Н. В., Щукіна О. В.}

Резюме. Метою досліджень було вивчення впливу на ростові процеси Allium cepa L. когерентних властивостей різних водних джерел і зразків дистильованої і природної води з перенесеними на них електрофрізичними властивостями оригінальних зразків.

Матеріал та методи. Реєстрували кірліанівське газорозрядне світіння крапель води на рентгенівських плівках. Використовували гістограми яскравості корони світіння, розраховували значення евклідової відстані для медіан висот стовпців гістограми, і для різниць медіан в сусідніх інтервалах. В ході досліджень проводили порівняння величин з аналогічними параметрами попередньо сформованих вибірок зображень типових вод (дистильована, водопровідна, з природних джерел поза і з територій монастирів), а також зразків води з встановленим типом і ступенем когерентності. Об'єктом ростового тесту були рослини цибулі - Allium cepa L. Оцінювали висоту проростків, довжину корінців, і визначали ïx суху масу.

Результати. Виявлено тотожність ознак когерентності у більшості зразків електрофізичних (енергоінформаційних) копій води з оригінальних джерел, відповідності між результатами ростового тесту і властивостями когерентності води. Мало місце збільшення біомаси тест-культури при вирощуванні на зразках з правообертальною когерентністю води в міру збільшення її ступеня. При лівообертальній поляризації когерентності води зі збільшенням її ступеня біомаса зменшується. Проведене дослідження показало можливість перенесення електрофізичних властивостей різних зразків природної води як на дистильовану воду, так і на інші зразки води з природних джерел.

Висновки. Експериментально продемонстровано можливість перенесення квантових властивостей жидкофазних об'єктів для приготування і використання біологічно активних речовин в сільському господарстві, біології та медицині без їх побічних ефектів. Кірліанфотографія води може бути використана в якості додаткового способу експрес-індикації фрізичного стану водних басейнів біосфери, в тому числі якості питних вод по їх когерентним властивостями.

Ключові слова: когерентність, вода, електрофрізичні водні копії, тест-культура, кірліанфротографрія.

УДК 573.4:614.777

\section{ВЛИЯНИЕ КОГЕРЕНТНЫХ СВОЙСТВ ВОДЫ \\ НА БИОЛОГИЧЕСКИЙ РОСТ РАСТЕНИЙ \\ Минцер О. П., Песоцкая Л. А., Горовая А. И., \\ Глухова Н. В., Щукина Е. В.}

Резюме. Целью исследований явилось изучение влияния на ростовые процессы Allium cepa L. когерентных свойств различных водных источников и образцов дистиллированной и природной воды с перенесенными на них электрофизическими свойствами оригинальных образцов.

Материал и методы. Регистрировали кирлиановское газоразрядное свечение капель воды на ренгеновской пленке. Использовали гистограммы яркости короны свечения, рассчитывали значения Евклидового расстояния для медиан высот столбцов гистограммы и для разниц медиан в соседних интервалах. В ходе исследований проводили сравнение величин с аналогичными параметрами предварительно сформированных выборок изображений типовых вод (дистиллированная, водопроводная, из природных источников вне и с территорий монастырей), а также образцов воды с установленным типом и степенью когерентности. Объектом ростового теста были растения лука - Allium cepa L. Оценивали высоту проростков, длину корешков и определяли их сухую массу. 
Результаты. Выявлены тождественность признаков когерентности у большинства образцов электрофизических (энергоинформационных) копий воды с оригинальных источников, соответствия между результатами ростового теста и свойствами когерентности воды. Имело место увеличение биомассы тест-культуры при выращивании на образцах с правовращающей когерентностью воды по мере увеличения ее степени. При левовращающей поляризации когерентности воды с увеличением ее степени биомасса уменьшается. Проведенное исследование показало возможность переноса электрофизических свойств различных образцов природной воды как на дистиллированную воду, так и на другие образцы воды из природных источников.

Выводы. Экспериментально продемонстрирована возможность переноса квантовых свойств жидкофазных объектов для приготовления и использования биологически активных веществ в сельском хозяйстве, биологии и медицине без их побочных действий. Кирлианфотография воды может быть использована в качестве дополнительного способа экспресс-индикации физического состояния водных бассейнов биосфреры, в том числе качества питьевых вод по их когерентным свойствам.

Ключевые слова: когерентность, вода, электрофизические водные копии, тест-культура, кирлианфотография.

\section{ORCID and contributionship:}

Ozar P. Mintser : 0000-0002-7224-4886 A,B,E,F

Ludmila A. Pesotskaya : 0000-0003-3425-6509 A,B,D,E,F

Alla I. Gorovaya : 0000-0002-6692-9053 B,D,E,F

Natalya V. Glukhova : 0000-0003-0817-5465 B,C

Olena S. Shchukina : 0000-0002-9543-1545 A,B,D

A - Work concept and design, B - Data collection and analysis,

C - Responsibility for statistical analysis, D - Writing the article,

E - Critical review, F - Final approval of the article

\section{CORRESPONDING AUTHOR}

\section{Ludmila A. Pesotskaya}

Dnipro State Medical University,

Internal Medicine Department

9, Vernadskoho Str., 9, Dnipro 49000, Ukraine

tel: +380982372567, e-mail: Ipesotskaya23@gmail.com

The authors of this study confirm that the research and publication of the results were not associated with any conflicts regarding commercial or financial relations, relations with organizations and/or individuals who may have been related to the study, and interrelations of coauthors of the article. 